\title{
6. Theorizing transformative innovations: the role of agency in real critical junctures
}

\author{
Lilja Mósesdóttir and Ivar Jonsson
}

\section{INTRODUCTION}

According to Schwab (2015), the fourth industrial revolution (4IR) is already underway. It was triggered by the fusion of the new technologies blurring the lines between the physical, digital, and biological worlds, that generates transformation not only of production and management but also of governance. New forms of collaboration will have to be developed to make use of the opportunities created by the fusion of new technologies across the economic and social spheres. Governments and regulatory agencies need to collaborate closely with business and civil society. The governance required is the one preserving the interest of the consumers and the public at large while continuing to support innovation and technological development.

We would like to argue that a move from producer-orientated innovation systems to systems of transformative innovation plays a crucial role in the 4IR involving the development of future alternatives. A shift towards transformative innovation systems requires innovation policy to take into account the interests of a larger number of stakeholders than before and to engage users and end-consumers in policy formation processes. Moreover, climate change, demographic shift and technological development are posing a threat to socio-economic and environmental sustainability such that there is a need for new ways of determining (broadening the scope of) the objectives of innovation and technical change. Hence, innovation policy will need to be mission-orientated (Mazzucato 2018), giving direction to economic growth and innovation in order to tackle societal and technological challenges. It is a huge challenge to build successful collaboration around systems of transformative innovation as it involves a much larger number of actors than in the producer-orientated innovation system. At the same time digital technology has made it easier to integrate 
interests of more people (big data analytics) and to engage varieties of actors at digital platforms (see e.g. OECD 2018, p. 30).

We claim that the present era is a period in which societies are facing the challenge of a shift in societal and technological regimes. Periods of this kind are marked by 'real critical junctures' in which stakeholders and political actors struggle for different alternatives in societal development after long periods of relatively stable institutions and actor relations. The force behind the struggles is shifting power positions of various actors due to techno-socio-economic change. During critical junctures, actors attempt to build coalitions around a shared vision of how future society is to be constituted (Jonsson 2016a; Mósesdóttir 2001; Mósesdóttir and Ellingsæter 2017). Hence, analysis of the present 'real critical juncture' requires that political power relations and the balance of power between stakeholders and other political actors are taken into account.

Contemporary economic theories of technical change and industrial revolutions under-theorize political agency. Contributions by economists such as Schwab $(2015 ; 2016)$ and neo-Schumpeterians (Freeman and Perez 1988; Mazzucato 2013) presume that the history of capitalism is characterized by technical change that led to industrial revolutions. In periods of industrial revolution, technical change requires that societies adjust to the needs of the emerging new technologies. Moreover, these scholars claim that societies need to find ways to generate consensus and coalitions among economic and political actors in order to adjust societal development to the requirements of the new technology. Various actors, especially the state, are presumed to have the role of generating new technology. Although highlighting the importance of actors in this respect, economists such as, for example, Schwab and the neo-Schumpeterians do not explain adequately what actually takes place when actors interact and build their coalitions.

We claim that the neo-Schumpeterian school has developed the most advanced research program (RP) to explain the interplay between, on the one side, technical change that induces long economic waves and, on the other side, institutional change in society. However, the neo-Schumpeterian RP suffers from a 'Lakatosian stagnation'. According to Lakatos, a RP is stagnating if its theoretical growth lags behind its empirical growth, that is, as long as it gives only post-hoc explanations either of chance discoveries or of facts anticipated by, and discovered in, a rival programme ('degenerating problemshift') (Lakatos 1970, p. 100). Following Lakatos' train of thought, it appears that the neo-Schumpeterian RP needs a 'progressive problemshift' for it to progress further. Hence, its theoretical growth must generate empirical growth in terms of predicting novel facts with some success. Moreover, the neo-Schumpeterian RP will only be successful as 
long as it can progressively explain more chance discoveries or facts than rival RPs, and 'supersede' them. We argue that a 'progressive problemshift' in the neo-Schumpeterian RP requires that the role of agency and a theory of 'real critical junctures' will be integrated into it. Theoretical integration of this kind enables the neo-Schumpeterian RP to consider how contextual specificity affects the interaction between actors. This shift would generate substantial empirical growth as part of the theoretical basis of the neoSchumpeterian RP.

In this chapter we attempt to contribute to a progressive problemshift by providing a theoretical framework that deepens our understanding of the role of agency in periods of 'real critical junctures'. Before we do that, we need to highlight what characterizes the present critical juncture in terms of the shift from 'producer-orientated innovation systems' to 'systems of transformative innovation'.

\section{SYSTEMS OF TRANSFORMATIVE INNOVATION (STI)}

The present technological revolution is a challenge to stakeholders and politicians as it requires economic and innovation policies that are very different from the traditional policies of the post-World War II era. The escalating political and economic polarization and environmental crisis calls for new framing of innovation systems that broadens the socioeconomic objectives of innovation activity compared to the traditional producer-orientated innovation systems (TISs) of today. At the same time, it requires closer and widened collaboration of stakeholders concerning common policy formation.

The TISs developed in two phases that accommodated the development of capitalist societies from Fordism to post-Fordism. ${ }^{1}$ A common feature of the TISs is that producers of goods and governments predominantly define their goals. The participation of users and consumers of goods and services in defining the goals of innovation is minimized. Concerns for social and environmental consequences, pollution and climate change are not emphasized as a necessary part of the goals of innovation.

The TISs of Fordism and post-Fordism differ in terms of the roles that the nation state plays and in terms of globalization. The Fordist phase emphasized national economic growth (import-substitution) and presumed that science and technology policy (STP) should aim at increasing economic welfare via a Fordist socio-technical system based on mass production and consumption controlled by Keynesian economic policies. The state's STP was influenced by the Cold War and limited to a particular 
field of innovation activities such as agriculture, defence, telecommunications, medical research, geological surveys, and civil engineering works.

The post-Fordist version of producer-orientated TISs took shape in the neo-liberal era in the 1980s. It emphasizes international competitiveness (export promotion) and globalization. STP aims at increasing economic welfare via a post-Fordist socio-technical system based on international specialization, corporate networks and alliances, innovation, partnerships, flexible specialization of production and market niches. National systems of innovation (NSI) that cover the items above become essential part of the STP.

In recent years, TISs have faced severe criticism from various stakeholders that point at its narrow anthropocentric worldview, undemocratic elitism and corporate social irresponsibility. The critique concerns TISs' lack of broader stakeholder collaboration in terms of framing technological options and directions. This framing is missing in the operation of innovation networks, although established through government intervention. Technocratic politics that reduce the aims of innovation policies to maximize economic growth continue to dominate innovation policy framing. The critiques' alternative or counter-framing to the TISs explicitly request participatory and democratic processes when goals of STPs are decided upon. This kind of restructuring of the formation of STPs presumes the importance of empowering users and end-consumers of goods and services to participate in identifying socio-environmental sustainable alternatives and to influence or take decisions regarding these alternatives (Schot and Steinmueller 2016).

It appears that the alternative framing of STI requires closer and widened collaboration of stakeholders concerning common policy formation. The collaboration on innovation between corporations, research institutions and public authorities was the main thrust of the TISs. The list of collaborating actors of the new STI will be much larger and include actors such as research institutions, actors in civil society (e.g. non-profit societies and/or firms, interest and issue organizations, NGOs and end-consumers/ users), corporations and public authorities. In short, it requires intensified collaboration and coalition building on stakeholders' activities of 'collective innovation and entrepreneurship'. It presumes collaboration between individuals within firms and institutions, as well as between firms and/or institutions on a national as well as international level. Such collaboration produces constellations of groups or social units which become relatively autonomous and who collectively form their aims and strategies despite contested views. Hence, collective innovation is a process of collaboration evolving on the grounds of interaction and purposeful formation of common goals of the participants of the coalitions in question (see Jonsson 1994; 2016a, pp. 177-87). 


\section{The Main Features of the Advancing Systems of Transformative Innovation}

The scope of framing STIs reflects a worldview that is quite different from its traditional producer-orientated counterpart, the TIS. Unlike the anthropocentric exploitative worldview of the TIS, STI emphasizes biocentric and socially responsible use of natural and human resources. Moreover, the scope of transformative innovation is societal; it aims at restructuring future societies so that human society can improve human well-being in terms of social and environmental sustainability and moral justice. STIs' view of agency supersedes the utilitarian view of the egoistic and rational 'homo economicus' that aims at maximizing economic welfare presuming conditions of perfect market competition. The idea of the sovereignty of the individual and market competition as a point of departure is replaced by democratic decision-making in which stakeholders interact and generate collective aims and means to realize social justice and environmental sustainability. Consequently, public intervention, citizen grassroots participation and social experiments are institutionalized as part of the transformative systems. Table 6.1 highlights the main characteristics of the scope and policy of the STI.

An increasing number of national and international political actors appear to jump on the STI bandwagon. Examples at hand are the European Commission's report Mission-Oriented Research \& Innovation in the European Union (Mazzucato 2018). The government of Finland has introduced experiments with citizen wages (Kangas 2016) and Danish municipalities have implemented transformative welfare policies in which local citizens at grassroots level take part in searching for and defining needs for technological innovation in the field of social services (Lauritzen 2012). The Norwegian government emphasizes transformative innovation in its research and development (R\&D) policy, which is financed and coordinated by the Norwegian Research Council's innovation strategy for the public sector 2018-23 (Norges forskningsråd 2018).

Western societies host varieties of capitalism that institutionalized and regulated markets in different ways. Their welfare states are also different in scope and scale. Hence, Western societies are based on different societal paradigms that are reflected in their different levels of state intervention in markets, various types of democracy, scope and scale of social services and ethical aims such as quality of life and attitudes towards preservation of nature. It appears from the discussion above that STIs will be impregnated with societal paradigms that emphasize increased public intervention in innovation activity and would emphasize societal objectives such as empowering of citizens, social and health well-being and environmental sustainability. At the same time, the implementation of STIs would depend 
Table 6.1 The system of transformative innovation of the 6th Kondratiev: innovation for biocentrism/sustainabilism 2020+?

\begin{tabular}{|c|c|}
\hline & $\begin{array}{l}\text { Social and biocentric transformation (social and ecological } \\
\text { sustainability promotion); } \\
\text { STI aims at generating a better world in terms of social and } \\
\text { environmental responsibility with democratic participation of } \\
\text { stakeholders; } \\
\text { Requires societal transformation and implementation of } \\
\text { socio-technical systems (STS) that are sustainable and involves } \\
\text { democratic participation of stakeholders, producers and } \\
\text { consumers }\end{array}$ \\
\hline $\begin{array}{l}\text { Rationale/ } \\
\text { Justification } \\
\text { for policy } \\
\text { intervention }\end{array}$ & $\begin{array}{l}\text { The central focus is on the preconditions of fundamental } \\
\text { systemic change in the interests of social, economic and } \\
\text { environmental sustainability; } \\
\text { Shortcomings of science, technology and innovation are } \\
\text { highlighted and issues of sustainability and poverty or } \\
\text { inequitable income distribution are addressed; } \\
\text { STI takes into account and critically evaluates who benefits from } \\
\text { social and technical change; } \\
\text { Technologies are constructed by powerful actors in line with } \\
\text { their worldviews and/or interests; } \\
\text { Alternative innovations offer greater potential for social } \\
\text { inclusion income equality; } \\
\text { This requires a science and technology politics that opens up } \\
\text { space for societal learning, public debate, deliberation and } \\
\text { negotiation; } \\
\text { Socio-technical transition research must build upon evolutionary } \\
\text { economics and STS with a focus on how to achieve } \\
\text { transformative change }\end{array}$ \\
\hline $\begin{array}{l}\text { Innovation } \\
\text { model and } \\
\text { actors }\end{array}$ & $\begin{array}{l}\text { Mixture of supply and demand driven innovation model that } \\
\text { aims at transformation of socio-technical systems (STS); } \\
\text { STS includes skills, infrastructures, industry structures, products, } \\
\text { regulations and policies, user preferences, and cultural factors } \\
\text { that co-evolve together in a socio-technical system; } \\
\text { System innovation involves social innovation, since the focus is not } \\
\text { only on the technological components, but on all the } \\
\text { components including user preferences, policies and the } \\
\text { perception of the value and culture by actors within the } \\
\text { system; } \\
\text { Socio-technical experiments are essential as there is no single } \\
\text { best pathway to sustainability, income equity and other socially } \\
\text { desirable goals awaiting discovery; } \\
\text { Innovation is assumed to be a search process, guided by social } \\
\text { and environmental objectives }\end{array}$ \\
\hline
\end{tabular}


Table 6.1 (continued)

\begin{tabular}{l|l}
\hline Policy & $\begin{array}{l}\text { Policy practices emphasize collective experimentation and } \\
\text { practices } \\
\text { learning, hence finding the means to facilitate and empower } \\
\text { those engaged in these processes is essential; } \\
\text { Reflecting on social and environmental needs is essential and the } \\
\text { search process has to be guided by improvements in anticipation } \\
\text { of collateral effects and consequences; } \\
\text { Developing forums and processes through which anticipation } \\
\text { might be feasible is a priority; } \\
\text { Processes similar to foresight activities and technology assessment } \\
\text { groups are feasible and should be developed further; } \\
\text { The aim of anticipation is to identify areas for experimentation } \\
\text { with socio-technical innovation }\end{array}$ \\
\hline $\begin{array}{l}\text { Alternative } \\
\text { or counter } \\
\text { framings } \\
\text { (ACFs) }\end{array}$ & $\begin{array}{l}\text { ACF would address the social and environmental challenges } \\
\text { through the implementation of capital-intensive solutions (e.g. } \\
\text { centralized energy production with big wind and solar farms, } \\
\text { the expanded use of nuclear energy and further development } \\
\text { of a global value chain of waste products; geo-engineering) and } \\
\text { technologies that aim to mitigate ex-post the impacts of carbon- } \\
\text { intensive development (e.g. carbon capture and storage); } \\
\text { In this ACF, actors focus on the economic growth agenda, while } \\
\text { distributional consequences (social and ecological costs) are of } \\
\text { secondary importance }\end{array}$ \\
\hline
\end{tabular}

Source: Based on Schot and Steinmueller (2016).

on tradition for collaboration among central actors and the countryspecific institutional framework. Hence, it would evolve in different forms and scope as well as speed of diffusion across Western societies.

We would expect that the Nordic countries with their sizable universalist welfare states and their tradition of neo-corporatist consensus making will have comparative advantage in implementing STIs. These countries have comparative advantage in terms of long traditions of citizens' empowering as well as public intervention and promotion of $R \& D$ in the field of health and social services as well as information and communications technology (ICT) and cybernetics. This last point brings us to the question of the role of the actors that define, decide and institutionalize research policies and the researchers who execute the actual R\&D. Without the contribution of these actors, the transformation of the present TISs to STIs will not come about.

As mentioned in the introduction above, it is a huge challenge to build successful collaboration and concertation on shifting the existing 
producer-orientated innovation system towards systems of transformative innovation. Moreover, research into preconditions for such a shift appears to suffer from a lack of a substantial theoretical framework for further research. We will now discuss the state of the art of theories in this field of research and their shortcomings.

\section{A SHIFT TOWARDS SYSTEMS OF TRANSFORMATIVE INNOVATION}

Until now, research into technical change and shifts in technological regimes have predominantly been analysed with the economic theories of scholars in the field of business management studies and neo-Schumpeterians. While the former group concentrates on current transformation that they term industrial revolution, the latter group works within a Schumpeterian framework of long-waves in economic history: the so-called Kondratievs.

Insofar as scholars in the field of business management studies emphasize agency, they focus on actors' responses to challenges of technical change at the micro-level of individuals and corporations. Moreover, they tend to presume that actors' responses have the evolutionary function of adjusting individuals' and corporations' endowments and skills to the needs of technical change (Schwab 2016; Brynjolfsson and McAfee 2014). Compared to business management approaches, the neo-Schumpeterians, Freeman and Perez (1988), provide a more comprehensive approach of the role of cultural, social and political 'institutions' in technological revolutions and their necessary adjustment to the needs of new technological regimes. However, the business management and the neo-Schumpeterian approaches presume a techno-determinist view of institutional adjustment and actors' responses to technical change. They need more in-depth analysis of agency and actor-structure relations in societal development during the critical juncture.

A closer look at the neo-Schumpeterian approach is needed to develop a proper theoretical framework that takes into account agency when actors are engaged in collective coalition building. Freeman and Perez (1988) and Freeman and Louçã (2001) have tried to provide a holistic interpretation of the relationship between economic cycles and technological change, associating the upswing stage of long waves. In their analysis of the 5th Kondratiev, that is, the long economic wave based on ICT and rising biotechnology, Freeman and Perez (1988) used their framework of techno-economic paradigm to identify how the production and consumption spheres are fundamentally reconstructed to make better use of the opportunities created by ICT technology. According to Freeman and Perez 
(1988, pp. 60-61), the restructuring of the production sphere to accompany ICT technology involves more integrated systems of management, production and marketing systems, demand for high and low skill profiles and extensive computer-based investment. The shift towards the IT paradigm creates a persistent shortage of the high-level skills and persistent surplus capacity in the older energy-intensive industries. New social and political solutions/institutions are needed to solve these structural problems. These solutions are flexibility in hours of work, re-education and retraining systems, regional policies, new financial systems, possible decentralization of management and government, and access to data banks and networks at all levels as well as new telecommunication systems.

Freeman and Perez (1988, p. 61) acknowledge that more radical changes need to take place in the social and political institutions that were created during World War II but discuss neither the forces behind these changes nor their outcomes. They posit that innovation and technological changes lead to long waves of economic growth and assume that existing institutional structures and social relations will adjust to the requirements of the new technology and consequent production systems. Although this adjustment will appear in increased social unrest, Freeman and Perez have not provided any sound theory of which actors do generate this adjustment and how they do it. Hence, an analysis of the relation between agency-structuration-structure is missing (Jonsson 2016a). Freeman and Perez leave us with a rather hollow idea that the increased productivity and the growth of GDP during a long wave will outweigh by a large margin the cost of social unrest due to growing unemployment created by skill mismatches.

Because of their positive and acritical view of capitalism and markets, the neo-Schumpeterian economists have largely ignored the problems of unequal income distribution and social unrest that technical change fosters in uncontrolled markets. Following Pagano and Rossi (2011), Evangelista (2018) summarizes the main shortcomings of neo-Schumpeterians:

This technology-based perspective of economic growth reveals all its limits in interpreting what might be regarded as one of the major macroeconomic paradoxes materialized over the last decades: the mismatch between, on one hand, the strong opportunities offered by the technological achievements reached in the last few decades and, on the other hand, the parallel increase of economic and social inequalities, the permanence of a large amount of unsatisfied social and human needs, the unsustainable pressure that our economic model puts on natural resources and on the natural environment. (2018, p. 145).

The consequence of the paradox between the large economic benefits of technical change and lack of social progress is that the macroeconomic 
demand will not be able to absorb the increased productivity levels or the new commodities (Evangelista 2018, p.144). Freeman and Perez (1988, pp.59-60) assume that competition in capitalist societies can adjust demand to supply when socio-institutional systems (e.g. public re-skilling programmes) resolve 'market failures' (e.g. skill-mismatch). Evangelista (2018, p. 146) claims that this line of argument has been losing its explanatory power due to the amount of time that has passed since ICT first appeared and its widespread application.

Unlike neo-Schumpeterians, Schwab $(2015 ; 2016)$ acknowledges that inequality represents the greatest societal concern associated with the 4IR. The largest beneficiaries of innovation tend to be the innovators, shareholders and investors, which explains the rising gap in wealth between those dependent on capital versus labour. Moreover, machines will also displace many low-skilled workers while the diffusion of new technologies may result in a net increase in jobs for the highly skilled. According to Schwab (2015), growing polarization in income and wealth will in turn lead to an increase in social tensions. However, Schwab's analysis suffers from the same shortcoming as that of the neo-Schumpeterians. Both approaches lack an account of how social and political actors resist and/or seek to shape how the diffusion of new technologies proceeds. Instead they are preoccupied with taxonomical categorization of the main features of technical change. This critique of the neo-Schumpeterian and 4IR applies also to Evangelista's criticism of neo-Schumpeterians' legacy as they do not problematize the question of 'structuration' and the dynamic role of agency.

Kuhlmann and Rip's (2018) analysis of the next generation of innovation policies addressing Grand Challenges in transformative ways provides useful insights into the role of agency. According to Kuhlmann and Rip (2018, p. 451), agency is no longer central but distributed across different groups of actors and driven by institutional entrepreneurs such as civil society organizations. Hence, there is a need for horizontal coordination of constellations of actors in the form of concerted action or by mutually considering actions of others and proactively adjusting. Moreover, intermediary organizations such as funding agencies and spaces for interaction are important to enable and improve concerted action when there is no master strategy. Apart from being a part of the concertation, the government's role could be to provide reflection on the nature of the Grand Challenges, offer legitimation by, for example, creating platforms for collaboration, and to provide a link with democratic decision-making. Following Ornston and Schulze-Cleven (2015, p. 575), Kuhlmann and Rip (2018, p. 452) claim that concertation in practice will look like a patchwork that can result in broader, more diverse 'varieties of cooperation' in advanced capitalist 
economies. Hence, next generation innovation policies will be 'tentative' in addressing political and organizational complexities and uncertainties with explorative strategies (Kuhlmann et al. 2019; Kuhlmann and Rip 2018).

Surprisingly, Kuhlmann and Rip do not consider what actors other than the government can take on vertical coordination of distributed groups of actors. We claim that distributed agency and the need for missionorientated and experimental ways of addressing complex challenges open up opportunities for actors other than the government (national level) to become multi-level coordinators. As Hanssen et al. (2013, p. 883) argue, counties in a country like Norway can be a suitable actor to take on the role of multi-level coordinator as they are able to combine network and consensually based coordination with some form of hierarchical authority. Hence, the pressure may mount on regional authorities (meso-level) to allocate more resources to the coordination of constellations of actors at, on the one hand, the micro- and meso-levels and, on the other hand, governmental strategies at the macro-level. The growing importance of regional coordination means that coordination of institutions and entities at different levels does not necessarily occur at a higher level (cf. vertical coordination).

Power relations within and across constellations of actors are also missing in Kuhlmann and Rip's analysis of agency. The concept of 'power' is fundamental to the analysis of political science. However, different scholars define this concept differently. A frequently used definition of power in mainstream political science refers to the decision-making process (Poulantzas 1975, p. 104). Implicit in this definition is a similar thought as in the democratic theories of the 1950s and 1960s (Macpherson 1979); individuals or groups enter the abstracted and distinct political system or decision-making process and act rationally and in a goal-orientated way. Power defined in this way is too narrow and misleading. As Poulantzas (1975) has observed:

(i) it succumbs to a voluntarist conception of the decision-making process, through disregarding the effectiveness of the structures, and it is not able exactly to locate beneath the appearances the effective centres of decision inside which the distribution of power works; and (ii) it takes as a principle the 'integrationist' conception of society, from which the concept of 'participation' in decisionmaking is derived. (1975, p. 104).

We acknowledge that the concept of power has to take into account that political decisions are affected by the nature and form of the political structures in which such decisions are taken. Moreover, political decisions are determined by the 'balance of power' between the stakeholders and actors who interact in the particular contexts of decision-making and policy 
formation. By 'balance of power' we mean the relative power and capacity of the different actors to use political resources to organize support or opposition against state policy, institutions and forms of regulation and for or against each other's strategies.

In the present era, societies are facing the challenge of a shift in societal and technological regimes. Forces behind the shift are technosocio-economic changes such as digital technologies, growing inequality, crumbling trust in existing political institutions and financialization that are altering the balance of power between stakeholders and actors. Periods of this kind are marked by real critical junctures in which stakeholders and political actors struggle for different alternatives in societal development after long periods of self-reinforcing 'path dependency' characterized by relatively stable institutions and actor relations. During critical junctures, the actors attempt, despite their conflicting interests and visions, to build coalitions around a shared vision of how future society is to be constituted (Jonsson 2016b). Moreover, the actors proceed and begin to restructure society according to future visions in a process we highlight as 'process of structuration' and we will discuss below in the next section. ${ }^{2}$ In cases when changes are far reaching and touch upon all spheres of society and related societal paradigms, ${ }^{3}$ the struggle of actors may lead to changes on a societal scale that we would coin as an 'industrial revolution' or 'postindustrial revolution'.

Transformative change to an alternative path requires transformative innovation involving cooperation of various actors operating in various constellations of balance of power between the actors at the micro-, meso- and macro-levels. In the following section, we will focus on the main characteristics of a transformative shift in terms of the concept of 'process of structuration' that is constituted by the interplay between agency and structures in real critical junctures.

\section{TRANSFORMATIVE INNOVATION AND AGENCY}

For decades, innovation systems have been organized on the regional, national and international level. They have played an important role in generating growth and social well-being. Due to technological progress, demographic development and climate changes, various stakeholders and actors have started to focus their efforts/struggles on shaping how to organize innovation systems of the future. The challenge they face is how to decide the aims of future innovation, what stakeholders and actors should take part in deciding the objectives of innovation activities and whose interests should be prioritized. In this period of real critical juncture, the 


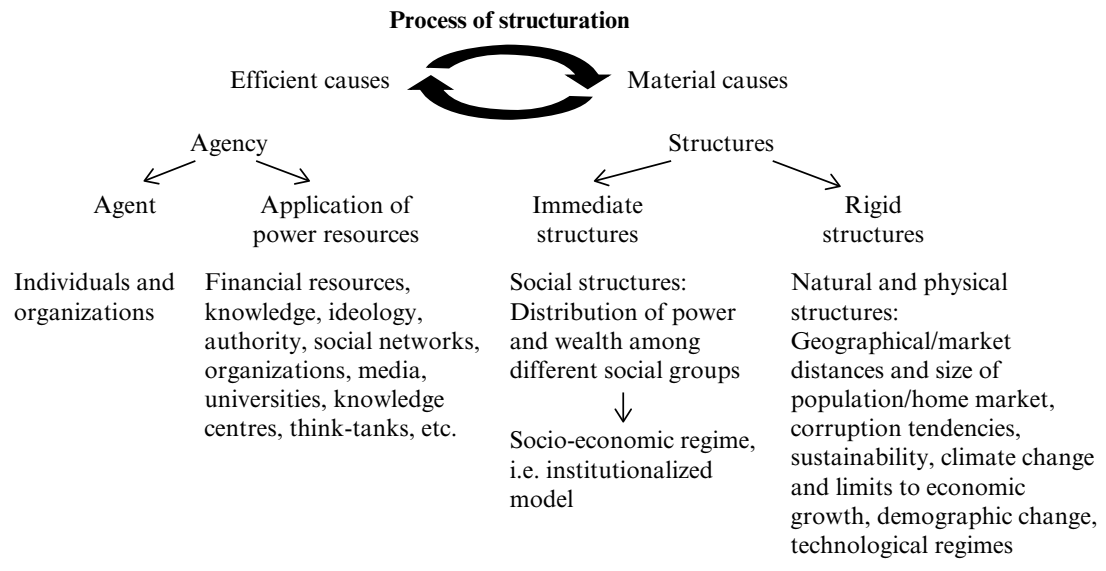

Figure 6.1 Agency and structuration

struggles of actors and stakeholders for different future alternatives call for 'processes of structuration'. Figure 6.1 highlights the main elements of a process of structuration.

The figure highlights that the process of structuration involves actors using power resources to mould social structures and regimes. Moreover, existing structures form the actors and their power resources. As power resources are unevenly distributed among actors, the outcome of the processes of structuration is likely to be skewed and in favour of those actors who have more power than the other actors, that is, those with a 'hegemonic position'. Hence, structuration is not 'voluntary'; it is contextually determined by the real critical juncture at hand.

Interest in studying 'critical junctures' and 'regime change' has increased in recent years among scholars of comparative politics. The concept of critical juncture is fundamental to historical institutionalism and its dualistic view of societal development. The main idea is that institutional development is characterized by, on the one hand, long periods of self-reinforcing 'path dependency' in which institutions are stable and reproduced and, on the other hand, short periods in which new forms of institutions will be decided and a new period of long-term self-reinforcing path dependency prevails.

This general dualist view of institutional change is often preoccupied with the mechanisms of 'institutional equilibria' but pay too little attention to critical junctures. When they do, they tend to explain the divergence during critical junctures in terms of structural, antecedent conditions rather than actions and decisions taken during the critical junctures 
themselves. This train of thought underestimates the role of actors in transformative processes of development. It tends to reduce explanations to correlations between abstract structural variables such as economic, cultural, ideological and organizational relations. It presumes a 'successionist' view of causation that characterizes 'closed systems' approaches that natural sciences adhere to by means of laboratory experiments (Sayer, 2000). An alternative approach would be to focus on contingency, that is, the role that powerful political actors play under conditions of critical juncture when decisions are taken concerning an alternative future institutional arrangement. This approach suffers from a shortcoming that characterizes much mainstream political research that tends to reduce the analysis to political decision-making processes, participants in such processes and their political resources. Moreover, this approach presumes that structures and their constraints have somehow temporarily moved from the scene so that the existing social and power relations are not effective in critical junctures. The result is that actors' decisions are presumed to be voluntarist.

Rather than treating contingency as 'voluntarist contingency', we would adhere to the idea that critical contingency is better seen as 'real contingency', as constraints of structures have temporarily diminished, but not disappeared. A 'real critical contingency' approach is rooted in an ontological view of causality which assumes that when actors or 'agents' transform societal institutions in concrete contexts, their actions, aims and choices are partly limited by the inertia of institutions, social structures and power relations that constitute the context they attempt to change. It presumes a view of causation that characterizes 'open systems' approaches predominant in social sciences. In the social world, 'open systems' prevail and they are characterized by causality in which the same causal factor can produce different outcomes and alternative developmental opportunities. Hence, different contexts with different actors and their relations would tend to lead to different outcomes. Outcomes are neither teleological nor predetermined (Sayer 2000). Frequently, the concept of critical juncture is used in post-festum analyses that deduce what is 'critical' in a juncture from events that take place after the critical instance. Unlike this, we define the 'critical' aspect of a juncture with reference to actions taking place in the context prior to path dependency. Agency presumes that collective and individual agents reflect on the opportunities for transforming structural hindrances in the existing material context and consequently organize necessary resources for change. Opportunities for transforming the material context in question are identified and the ideologically preferred state of affairs is realized. Moreover, the efficiency of agency, as an 'efficient cause' ${ }^{4}$ of change, depends on the emergent properties allowed by existing 
social structures. Consequently, causality can neither be reduced to agents' intentions, voluntary actions and/or discourse nor to determination of their actions by structures. Let us not forget that structures of social relations usually contain properties that can lead to different results in terms of transformed social relations.

The process of structuration takes place in particular periods that are part of long-term structural change, referred to as material causes in Figure 6.1 above. This must be kept in mind as the contexts of real critical junctures are historically different and the balance of power between actors is qualitatively different in different real critical junctures. Today, it is possible to identify at least two developments affecting the balance of power that have more or less prevailed since World War II: the growing dominance of the financial sector and digital technologies, while the post-World War II era was characterized by dominance of the industrial corporate sector and assembly line technologies of mass-production.

In recent decades, financial capital has gradually gained a stronger power position due to the process of 'financialization' of societies and economies (Foster and Magdoff 2008). According to Deutschmann 2011 (cited in Hahn 2019, p.924), financialization of the economy involves two areas of change related to firms and their institutional environment. First, the increasing importance of investment banks and private pension funds as traditional banks have moved towards promising investment activities and the ageing challenge has led to a growth in pension savings. Secondly, institutional investors have become important players not only in financial markets but also in firms as public shareholders. This process of financialization has swung the power balance from cooperation in the production sector towards the financial sector (Berghoff 2016; Deutschmann 2011).

According to a recent study by Battiston et al. (2018), financialization in the EU has had a negative effect on economic growth, innovation and inequality. Economic growth is depressed as financialization implies that a larger fraction of credit is directed towards unfruitful investment projects (higher housing prices), possibly generating economic crises. Financialization also has a negative impact on innovation as the separation between actors taking risks from innovation and actors extracting rents from innovation entails a lower share of reinvested profits (short-termism). Finally, financialization contributes to inequality by strengthening top earners' bargaining power in terms of higher wages and lower taxation, as well as by burdening public budgets with fiscal assistance to financial institutions in times of crisis. Hence, financialization may hamper innovation activities as they seek to broaden their scope of priorities and the involvement of actors in order to achieve greater socio-economic sustainability. 
Technological innovations are also putting pressure on the prevailing balance of power between different economic actors. Examples are e-commerce and digital platforms that are shifting the balance of power to digital giants (Google and Facebook) and customers. The enormity of scale in the digital economy has created digital giants/monopolies using intangible barriers (e.g. closed membership) to entry by crowding out competition. Hence, the phenomenon of 'winner-takes-all' or a situation where a product or business that is ahead, gets further ahead and one that loses advantage, loses further. Digitalization offers not only cost advantages through operational efficiency but also channels for greater customization (business analytics). With low or no costs for end users, digital monopolies seek to cut down supply costs (Amazon) and use the customer base to identify market trends and to implement customerspecific, personalized pricing, as, for example, Uber (Ghotgalkar et al. 2017; Schwab 2015).

In addition to the two trends discussed above, a demographic shift on a global scale has been taking place in recent decades. The shift involves a qualitative change in the world population in terms of its ageing, and a quantitative jump in the growth of the world population. These changes are unfolding in an increasing scale of migration and the foreseeable need for a rise in expenditure on health services is creating fiscal challenges for states (World Economic Forum 2019; OECD 2014). The demographic change is part of the material causes mentioned in Figure 6.1. Eventually, humanity is faced with challenges that require new policies of transformative innovation and coalitions on a national and international scale.

The process of structuration in real critical junctures has its 'efficient causes' in agency, that is, actors and their use of power resources (se Figure 6.1). In the present era, the process of structuration is in its early stages in which actors respond to deepening institutional crises of legitimation of the ailing regime of Fordism and post-Fordism. The current situation is similar to that of the economic and political turmoil of the 1930s. During that period, capitalist economies went through economic, social and political polarization that led to increasing mistrust in liberal democracy and growing violent clashes between social classes and the eventual threat of civil war. As Kregel (2018, p. 149) puts it:

After ... the stock market break and then the failure to stem rising unemployment over the following three years culminating in the collapse of the financial system created an aura of increasing helplessness and desperation; a failure of a liberal democratic solution. Citizens marching in support of what were considered to be successful policy responses to the crisis by Fascist and Communist countries made the failure of traditional policies to reverse the crisis and its culmination in the national closure of banks more debilitating. 
It became the role of President F.D. Roosevelt to convince Congress and voters to accept the New-Deal policies that involved the creation of a concerted rejection of orthodox economic policies and acceptance of state interventionism (Kregel 2018, p. 164).

Following the collapse of the fascist regimes of Italy and Germany, the balance of power between capital and labour had shifted towards the trade unions in Europe. The success of Fordism required consensus on developing a tripartite collaboration of the main organized interests, that is, trade unions, employers' unions and the state (often called neo-corporatism). These three actors had in common a high level of hierarchical organization and centralization of power in the hands of the elites of the tripartite system.

In the late 1970s, Keynesian anti-cyclical policies proved ineffective and neo-liberalist policies and regimes spread their roots during the 1980s. Diffusion of ICT technology and automation, flexible specialization, deregulation, globalization, outward FDI and rising unemployment reduced membership of trade unions. All these factors undermined the institutionalized balance of power of neo-corporatism and accelerated the global power position of the financial sector in the new era of postFordism (Giorgi 2017).

Post-Fordism, with its neo-liberal policies, contributed to the development of intensified uneven income and wealth distribution. As Oxfam reports, increasing amounts of income and wealth go to those at the very top. At the same time, the middle classes are losing out just as much as the poorest people. In rich countries, the middle classes often see their incomes stagnate. A core reason for this inequality is that 'between 1980 and 2016, the poorest $50 \%$ of people only received 12 cents in every dollar of global income growth. By contrast, the richest $1 \%$ received 27 cents of every dollar' (Oxfam 2019, p. 11).

The key factors behind the growing inequalities as well as innovation, productivity gains and economic growth are globalization and technological progress involving, among others, outsourcing, increased competition from low-wage countries, and automation. The financial crisis of 2008 exacerbated these inequalities as many saw their homes, jobs and much of their wealth and retirement savings disappear. The aftermath of the crisis witnessed fast-spreading fear and anxiety in Western societies and rapidly increasing distrust in the established political system of liberal democracy and in the political elites of these societies. This situation resembles the political crisis that evolved following the financial crisis in the Great Depression of the 1930s. Indeed, research indicates that the aftermaths of the financial crisis in the 1930s and after 2008 follow a rather similar pattern in terms of how the voters and political actors respond. 
In their study of the implications of the Great Recession for voting and general trust, using regional data across Europe, Algan et al. (2017) found that a rise in unemployment goes hand in hand with a fall in political trust and a rise in political extremism. These findings are in line with those of Funke et al. (2016), who studied 20 advanced economies over the years 1870-2014. They found that political polarization increases after financial crises and voters seem to be particularly attracted to the political rhetoric of the extreme Right after a crisis. These results correspond to those of a recent study by de Bromhead et al. (2012) focusing on the electoral consequences of crises in the 1920s and 1930s. Moreover, Funke et al. (2016) found that implementation of policies and reforms became more difficult after financial crises, irrespective of which parties are in power.

The aftermaths of the financial crisis in the late 1920s and 1930s generated a real critical juncture that gave birth to the post-World War II Fordism and subsequent path dependency. This real critical juncture developed in four main phases. In the first phase, polarization of capitalist economies and escalating severe social unrest urged political leaders and intellectuals to define and analyse the fundamental reasons for the situation. Consequently, a search period set in when feasible solutions to the problems were defined, new ways of thinking promoted and policies formulated. We call this first phase of a real critical juncture 'the search phase'. A second phase starts when actors and the public in general become increasingly disillusioned with policies created in the search phase that proved to be ineffective in solving the pressing socio-economic problems to the extent that they escalate. We term this second phase 'the phase of realism'. A third phase begins when actors and stakeholders are convinced that radical changes are necessary and they start to build coalitions for concerted strategies of societal transformation. We call this third phase 'the phase of consensus building'. A fourth and final phase is reached when radical strategies of transformative change have been implemented and the public accepts its advances and expects that it will generate general well-being. A move from one phase to another in the critical juncture is not necessarily linear as backlashes or lock-in situations may occur when regressive groups gain political capacities to stop or reverse transformative changes.

We can now analyse the main features of the present real critical juncture in terms of these phases. The financial crisis of 2008 has prolonged the first phase in the critical juncture as it temporarily reduced the political polarization as many voters turned from left-wing parties to right-wing parties. However, polarization in wealth and income continued to increase after the crisis, especially in the hardest hit countries, which in turn has enhanced the legitimization crisis of the current institutional 
regimes. The growing legitimization crisis has intensified the search of those in power for alternative solutions to the complex challenges of the techno-socio-economic changes. However, advanced capitalist societies have not yet reached the second phase in the critical juncture, the phase where actors have become disillusioned with the outcomes of experimental and often only incremental changes to institutional regimes that have repeatedly demonstrated an incapacity to provide sustainable socio-economic welfare for most people. The third phase will be reached when powerful constellations of actors are able to agree on, mobilize support for and implement transformative changes to the current social and political institutions or, in other words, what we term systems of transformative innovation. The final phase in the critical juncture occurs when various systems of transformative change have managed to produce relatively stable institutions and actor relations paving the way for a period of self-reinforcing 'path dependency'.

\section{CONCLUSION}

In this chapter we have attempted to contribute to further development of the neo-Schumpeterian research programme by theorizing the role of actors in real critical junctures. The aim is to achieve a 'progressive problemshift' in the neo-Schumpeterian research programme in order to generate substantial empirical growth as part of its revitalized theoretical basis.

The present cybernetic, bio-technological revolution is having widespread effects across different sectors, creating winners and losers, which puts pressure on the prevailing balance of power between different actors. Hence, we have entered a period marked by a real critical juncture in which a variety of stakeholders and political actors struggle for various alternatives in societal development.

We argue in this chapter that a transformative change to a more sustainable socio-economic development requires transformative innovation involving cooperation of different actors around mission-orientated and experimental policies in various constellations at the micro-, meso- and macro-levels. How the actors shape transformative change depends on the challenges and opportunities created by the context of the real critical juncture, balance of power and their capacity to collaborate on restructuring society as well on the form and extent to which their efforts in multilevel networks are coordinated.

Our improvement of the neo-Schumpeterian research programme involves connecting innovation activities to distributed agency, power 
relations, cooperation and contestation, multilevel coordination and real critical junctures. Hence, we provide a theoretical framework for future empirical analyses of the interaction between various stakeholders and political actors during different phases of critical juncture periods of transformation focusing on (conflicting) interests, shifts in power relations and the nature of coalition building as well as its (lack of) multilevel coordination. Based on our contribution, we presume further studies may tackle research questions such as: What groups of actors are searching for future alternatives and for what reasons? Are groups of actors at either the micro-, meso- or macro-level attempting to build coalitions around certain future developmental models and what barriers do they encounter and why? Who is participating in these coalitions and for what reasons? To what extent are innovation policies mission-orientated, experimental and transformative? To what extent are the phases in real critical junctures valid for different case studies and to what extent are our four phases able to generate empirical growth in terms of predicting novel facts?

\section{NOTES}

1. For further reading on the concepts of Fordism and post-Fordism see Aglietta (1979), Hirsch and Roth (1986) and Lipietz (1987).

2. See Giddens (1984) for a discussion of the concept of structuration.

3. For analysis of different 'institutional' contexts in terms of 'societal paradigms' for comparative studies, see Jonsson (2001). There are four types of societal paradigms. 'Techno-economic paradigms' refer to ideas about what constitutes the best practices and means of organizing production, services and consumption in general. Secondly, 'power-political paradigms' refer to ideas about how 'collective' decision-making is best organized and its enforcement institutionalized. Thirdly, 'reproduction-social paradigms' refer to ideas about the roles different social groups and institutions should play in regard to sexuality, biological reproduction, care of children, old persons and the disabled, and socialization. Fourthly, 'ethical-prescriptive paradigms' refer to worldviews and general ideas about right and wrong conducted in different situations, the aims and quality of life and attitudes towards preservation of nature.

4. See further discussion on efficient and material causes in Archer (1995, pp. 90 and 153) and Lewis (2000, pp. 260 and 264).

\section{REFERENCES}

Aglietta, M. 1979, A Theory of Capitalist Regulation: The US Experience, London: New Left Books.

Algan, Y., Guriev, S., Papaioannou, E. and Passari, E. 2017, 'The European trust crisis and the rise of populism', Brookings Papers on Economic Activity (Fall), pp. 309-82. 
Archer, M. 1995, Realist Social Theory: The Morphogenetic Approach, Cambridge: Cambridge University Press.

Battiston, S., Guerini, M., Napoletano, M. and Stolbova, V. 2018, 'Financialization in EU and the effects on growth, inequality and financial stability', ISIGrowth, accessed 25 May 2019 at: http://www.isigrowth.eu/wp-content/uploads/2018/07/ working_paper_2018_36.pdf.

Berghoff, H. 2016, 'Varieties of financialization? Evidence from German industry in the1990s', Business Historical Review, 90(1), 81-108.

Brynjolfsson, E. and McAfee, A. 2014, The Second Machine Age: Work, Progress, and Prosperity in a Time of Brilliant Technologies, New York: W.W. Norton \& Company.

De Bromhead, A., Eichengreen, B. and O'Rourke, K.H. 2012, 'Right wing political extremism in the Great Depression', Discussion Papers in Economic and Social History, no. 95, University of Oxford.

Deutschmann, C. 2011, 'Limits to financialization', European Journal of Sociology, 52(3), 347-89.

Evangelista, R. 2018, 'Technology and economic development: the Schumpeterian legacy', Review of Radical Political Economics, 50(1), 136-53.

Foster, J.B. and Magdoff, F. 2008, The Great Financial Crisis: Causes and Consequences, New York: Monthly Review Press.

Freeman, C. and Louçã, F. 2001, As Time Goes By: From the Industrial Revolutions to the Information Revolution, Oxford: Oxford University Press.

Freeman, C. and Perez, C. 1988, 'Structural crises of adjustment: business cycles and investment behaviour', in G. Dosi, C. Freeman, R. Nelson, G. Silverberg and L. Soete (eds), Technical Change and Economic Theory, London: Pinter Publishers.

Funke, M., Schularick, M. and Trebesch, C. 2016, 'Going to extremes: politics after financial crises, 1870-2014', European Economic Review, 88, 227-60.

Ghotgalkar, V., Baltora, J., Rosenberg, M.K. and Riley, T. 2017, 'How the digital economy is changing corporate pricing and inflation', Investment Research, 22 August.

Giddens, A. 1984, The Constitution of Society: Outline of the Theory of Structuration, Cambridge: Polity Press.

Giorgi, A. 2017, Re-thinking the Political Economy of Punishment: Perspectives on Post-Fordism and Penal Politics, London: Routledge.

Hahn, K. 2019, 'Innovation in times of financialization: do future-oriented innovation strategies suffer? Examples from German industry', Research Policy, 48(4), 923-35.

Hanssen, G.S., Mydske, P.K. and Dahle, E. 2013, 'Multi-level coordination of climate change adaptation: by national hierarchical steering or by regional network governance?', Local Environment: The International Journal of Justice and Sustainability, 18(8), 869-87.

Hirsch, J. and Roth, R. 1986, Das Neue Gesicht des Kapitalismus: Vom Fordismus zum Post-Fordismus, Hamburg: VSA-Verlag.

Jonsson, I. 1994, 'Collective entrepreneurship and micro-economies', in T. Greifenberg (ed.), Sustainability in the Arctic, Aalborg: NARF/Aalborg University Press.

Jonsson, I. 2001, 'Societal paradigms and rural development - a theoretical framework for comparative studies', in L. Granberg, I. Kovach and T. Hilary (eds), Europe's Green Ring, Aldershot: Ashgate Publishing. 
Jonsson, I. 2016a, 'Economic crisis and real critical junctures - on the decay of the political party system of Iceland', The Polar Journal, 6(1), 131-51.

Jonsson, I. 2016b, The Political Economy of Innovation and Entrepreneurship from Theories to Practice, London: Routledge.

Kangas, O. 2016, From Idea to Experiment: Report on Universal Basic Income Experiment in Finland, Helsinki: Kela.

Kregel, J. 2018, 'What we could have learned from the New Deal in dealing with the recent global recession', Review of Social Economy, 76(2), 147-66.

Kuhlmann, S. and Rip, A. 2018, 'Next generation innovation policy and grand challenges', Science and Public Policy, 45(4), 448-54.

Kuhlmann, S., Konrad, K. and Stegmaier, P. 2019, 'Tentative governance in emerging science and technology - conceptual introduction and overview', Research Policy, 48(5), 1091-7.

Lakatos, I. 1970, 'History of science and its rational reconstructions', Boston Studies in the Philosophy of Science, pp.91-136.

Lauritzen, J.R.K. 2012, Social Innovation in Local Government - Experiences from Denmark, Produced as Part of 'Next Practice - New Forms of Innovation', Danish Technological Institute, Centre for Policy and Business Analysis.

Lewis, P. 2000, 'Realism, causality and the problem of social structure', Journal for the Theory of Social Behaviour, 30(3), 249-68.

Lipietz, A. 1987, Mirages and Miracles: The Crisis of Global Fordism, London: Verso.

Macpherson, C.B. 1979, The Life and Times of Liberal Democracy, Oxford: Oxford University Press.

Mazzucato, M. 2013, The Entrepreneurial State, London: Anthem Press.

Mazzucato, M. 2018, Mission-oriented Research \& Innovation in the European Union: a Problem-solving Approach to Fuel Innovation-led Growth, Paris: European Union.

Mósesdóttir, L. 2001, The Interplay Between Gender, Markets and the State in Sweden, Germany and the United States, London: Routledge.

Mósesdóttir, L. and Ellingsæter, A.L. 2017, 'Ideational struggles over women's part-time work in Norway: destabilizing the gender contract', Economic and Industrial Democracy, 6 January, https://doi.org/10.1177/0143831X16681483.

Norges forskningsråd 2018, Innovasjon i offentlig sector: forskningsrådets strategi 2018-2023, Norges forskningsråd, Oslo, accessed 22 January 2020 at https://www. forskningsradet.no/siteassets/publikasjoner/1254032549913.pdf.

OECD 2014, 'Policy challenges for the next 50 years', OECD economic, policy paper, no. 9, Paris: OECD.

OECD 2018, OECD Science, Technology and Innovation Outlook 2018, Paris: OECD.

Ornston, D. and Schulze-Cleven, T. 2015, 'Conceptualizing cooperation coordination and concertation as two logics of collective action', Comparative Political Studies, 48(5), 555-85.

Oxfam 2019, Public Good or Private Wealth?, Oxford: Oxfam.

Pagano, U. and Rossi, M.A. 2011, 'Property rights in the knowledge economy', in E. Brancaccio and R. Fontana (eds), The Global Economic Crisis, Abingdon: Routledge, pp. 284-97.

Poulantzas, N. 1975, Political Power and Social Classes, London: New Left Books. Sayer, A. 2000, Realism and Social Science, London: SAGE Publications.

Schot, J. and Steinmueller, W.E. 2016, 'Framing innovation policy for 
transformative change: innovation policy 3.0', Brighton: Science Policy Research Unit (SPRU).

Schwab, K. 2015, 'The fourth industrial revolution: What it means and how to respond', Foreign Affairs, 12 December.

Schwab, K. 2016, The Fourth Industrial Revolution, Geneva: World Economic Forum.

World Economic Forum 2019, The Global Risks, Report 2019, 14th edn, Geneva: World Economic Forum. 